\title{
THE LIVING AL-QUR'AN: Beberapa Perspektif Antropologi
}

\author{
Heddy Shri Ahimsa-Putra \\ Universitas Gadjah Mada Yogyakarta \\ e-mail: ahimsa_putra@yahoo.com
}

\begin{abstract}
This article deals with the meanings of the living al-Qur'an and how as socio-cultural phenomena they can be studied anthropologically. The living al-Qur'an here is interpreted as the meanings given by the people (Moslem as well as non-Moslem) to al-Qur'an and how these meanings are actualized in their daily lives. Some of its social meanings are given here and explained. Seen in that way, the living al-Qur'an can thus be studied by using anthropological perspectives, such as acculturation perspective or diffusion perspective, functional perspective, structural perspective, phenomenological perspective and hermeneutical or interpretive perspective.

$* * *$

Artikel ini membahas tentang makna al-Qur'an hidup dan bagaimana sebagai fenomena sosial bidaya al-Qur'an dapat dikaji secara antropologis. Al-Qur'an yang hidup di sini diinterpretasikan sebagai makna yang diberikan oleh masyarakat (Muslim maupun non-Muslim) terhadap al-Qur'an dan bagaimana makna ini diaktualisasikan dalam kehidupan mereka sehari-hari. Beberapa makna sosialnya akan dibahas di sini dan akan dijelaskan. Dengan cara seperti itu al-Qur'an hidup dapat dikaji secara antropologis, yaitu dengan perspektif akulturasi, difusi, fungsional, fungsional struktural, fenomenologi, dan hermeneutik atau interpretif.
\end{abstract}

Keywords: living al-Qur'an, fenomena, perspektif antropologi

Walisongo, Volume 20, Nomor 1, Mei 2012 


\section{A. Pendahuluan}

Beberapa tahun yang lalu muncul wacana baru di kalangan dosen dan mahasiswa IAIN — yang sebagian kini telah berganti nama menjadi UIN-mengenai perlunya kajian tentang al-Qur'an dalam pengertian yang lebih luas, yakni sebagai "The Living al-Qur'an". Al-Qur'an diinginkan untuk tidak hanya dimaknai sebagai sebuah kitab suci, tetapi juga sebuah kitab yang isinya terwujud atau berusaha diwujudkan dalam kehidupan sehari-hari. ${ }^{1}$ Dengan begitu studi tentang al-Qur'an akan mencakup bukan hanya al-Qur'an sebagai kitab dengan berbagai macam tafsirnya, tetapi juga berbagai upaya untuk merealisasikan tafsir-tafsir tersebut dalam kehidupan nyata, dalam hubungan antarsesama manusia dan hubungan manusia dengan lingkungan alamnya.

The Living al-Qur'an atau "al-Qur'an yang hidup" adalah ungkapan yang tidak asing bagi kebanyakan orang Islam. Di kalangan mereka ungkapan ini dapat dimaknai berbagai macam. Pertama, ungkapan tersebut bisa bermakna "Nabi Muhammad" dalam arti yang sebenarnya, yaitu sosok Nabi Muhammad SAW, karena menurut keyakinan umat Islam akhlak Nabi Muhammad SAW adalah al-Qur'an. Dalam kitab itu disebutkan bahwa pada diri Nabi Muhammad SAW terdapat contoh yang baik. Hal ini diperkuat oleh hadits dari Siti Aisyah r.a., yang mengatakan bahwa akhlak Nabi Muhammad SAW adalah al-Qur'an. Artinya, beliau selalu berperilaku dan bertindak berdasarkan pada apa yang terdapat dalam al-Qur'an. Oleh karena itu, Nabi Muhammad SAW adalah "alQur'an yang hidup," al-Qur'an yang mewujud dalam sosok manusia.

Kedua, ungkapan tersebut juga bisa mengacu pada suatu masyarakat yang kehidupan sehari-harinya menggunakan al-Qur'an sebagai kitab acuannya. Mereka hidup dengan mengikuti apa-apa yang diperintahkan dalam alQur'an dan menjauhi hal-hal yang dilarang di dalamnya, sehingga masyarakat tersebut seperti "al-Qur'an yang hidup," al-Qur'an yang mewujud dalam kehidupan sehari-hari mereka. Kita tidak mempunyai contoh konkret dari masyarakat semacam ini, dan mungkin juga masyarakat semacam ini belum pernah ada, karena dalam masyarakat Islam yang manapun selalu saja terdapat bentuk-bentuk kehidupan, pola-pola perilaku, tindakan dan aktivitas yang tidak berdasarkan al-Qur'an. Press, 2007).

${ }^{1}$ Lihat M. Mansyur, dkk., Metodologi Penelitian Living Qur'an dan Hadits, (Yogyakarta: TH. 
Ketiga, ungkapan tersebut juga dapat berarti bahwa al-Qur'an bukanlah hanya sebuah kitab, tetapi sebuah "kitab yang hidup," yaitu yang perwujudannya dalam kehidupan sehari-hari begitu terasa dan nyata, serta beranekaragam, tergantung pada bidang kehidupannya. Perwujudan al-Qur'an dalam kegiatan ekonomi misalnya, tentu akan berbeda dengan perwujudan al-Qur'an dalam kegiatan politik atau dalam kehidupan keluarga. Selanjutnya, cara mewujudkan al-Qur'an dalam kehidupan sehari-hari ini juga sangat beranekaragam, tergantung pada pemaknaan yang diberikan terhadap al-Qur'an itu sendiri sebagai kumpulan Firman Allah SWT, Sabda Tuhan, yang juga tidak dapat lepas dari pemaknaan manusia tentang Tuhan itu sendiri, tentang Allah SWT. Dalam pengertian seperti ini, al-Qur'an dapat mewujud di tengah-tengah masyarakat yang tidak semua warganya beragama Islam, sementara perwujudannya dalam kehidupan orang Islam juga sangat bervariasi.

Dalam tulisan ini saya mencoba untuk memaparkan berbagai pemaknaan orang Islam di Indonesia terhadap al-Qur'an sebagai sebuah kitab yang berisi sabda-sabda Allah SWT dan bagaimana pemaknaan ini kemudian mewujud dalam kehidupan sehari-hari, atau menjadi dasar bagi pola-pola perilaku dan tindakan tertentu, yang bahkan kemudian kadang-kadang terlihat seperti berlawanan dengan prinsip dasar dari ajaran dalam al-Qur'an itu sendiri, yakni tauhid, mengesakan Tuhan. Tentu di sini saya tidak akan berbicara tentang "benar" dan "salah"-nya tafsir-tafsir yang diberikan oleh kelompok atau golongan sosial tertentu terhadap al-Qur'an tersebut, karena soal "benar dan "salah" berada di luar arena perbincangan yang memandang gejala Qur'anisasi kehidupan sosial dan budaya lewat sudut pandang antropologi. Selanjutnya, saya paparkan juga di sini beberapa pendekatan atau paradigma dalam antropologi yang dapat dan strategis untuk digunakan dalam penelitian mengenai The Living al-Qur'an.

\section{B. The Living al-Qur'an dan Animal Symbolicum}

Sejumlah peneliti sebenarnya telah memberikan definisi tentang The Living al-Qur'an. Syamsudin ${ }^{2}$ misalnya, mengatakan bahwa "Teks al-Qur'an yang 'hidup' dalam masyarakat itulah yang disebut The Living Qur'an,

2 Syamsudin, S., "Ranah-ranah Penelitian dalam Studi al-Qur'an dan Hadis” dalam M. Mansyur dkk., Metodologi Penelitian Living Qur'an dan Hadis, (Yogyakarta: TH. Press, 2007), h. xiv. 
sementara pelembagaan hasil penafsiran tertentu dalam masyarakat dapat disebut dengan the living tafsir". Apa yang dimaksudnya dengan "Teks alQur'an yang hidup dalam masyarakat"? Tidak lain adalah "respons masyarakat terhadap teks al-Qur'an dan hasil penafsiran seseorang. Termasuk dalam pengertian 'respons masyarakat' adalah resepsi mereka terhadap teks tertentu dan hasil penafsiran tertentu. Resepsi sosial terhadap al-Qur'an dapat kita temui dalam kehidupan sehari-hari, seperti pentradisian bacaan surat atau ayat tertentu pada acara dan seremoni sosial keagamaan tertentu. Sementara itu, resepsi sosial terhadap hasil penafsiran terjelma dalam dilembagakannya bentuk penafsiran tertentu dalam masyarakat, baik dalam skala besar maupun kecil."

Penulis lain, M. Mansur, berpendapat bahwa pengertian The Living Qur'an sebenarnya bermula dari fenomena Qur'an in Everyday Life, yang tidak lain adalah "makna dan fungsi al-Qur'an yang riil dipahami dan dialami masyarakat Muslim."3 Maksud penulis di sini-sejauh saya bisa memahaminya-adalah "praktik memfungsikan al-Qur'an dalam kehidupan praksis, di luar kondisi tekstualnya". Pemfungsian al-Qur'an seperti itu muncul karena adanya "praktek pemaknaan al-Qur'an yang tidak mengacu pada pemahaman atas pesan tekstualnya, tetapi berlandaskan anggapan adanya "fadhilah" dari unit-unit tertentu teks al-Qur'an, bagi kepentingan praksis kehidupan keseharian umat."4

Living Qur'an juga dapat diartikan sebagai "fenomena yang hidup di tengah masyarakat Muslim terkait dengan Qur'an ini sebagai objek studinya."5 Oleh karena itu, kajian tentang Living Qur'an dapat diartikan sebagai kajian tentang "berbagai peristiwa sosial terkait dengan kehadiran Qur'an atau keberadaan Qur'an di sebuah komunitas Muslim tertentu."6 Dengan pengertian seperti ini, maka "dalam bentuknya yang paling sederhana" The Living Qur'an tersebut "pada dasarnya sudah sama tuanya dengan Qur'an itu

${ }^{3}$ M. Mansyur, dkk., Metodologi Penelitian Living Qur'an dan Hadis, (Yogyakarta: TH. Press, 2007), h. 5.

${ }^{4}$ Ibid., h. 4.

${ }^{5}$ Ibid., h. 7.

6 Ibid., h. 8. 
sendiri."7 Meskipun demikian, praktek-praktek tersebut belum menjadi objek kajian penelitian mengenai al-Qur'an, sampai ketika para ilmuwan Barat tertarik untuk meneliti fenomena Living Qur'an tersebut.

Penulis yang lain lagi, Muhammad Yusuf, mengatakan bahwa "respons sosial (realitas) terhadap al-Qur'an... dapat dikatakan Living Qur'an. Baik itu al-Qur'an dilihat masyarakat sebagai ilmu (science) dalam wilayah profane (tidak keramat) di satu sisi dan sebagai buku petunjuk (hudā) dalam yang bernilai sakral (sacred) di sisi yang lain."

Studi mengenai Living Qur'an “adalah studi tentang al-Qur'an tetapi tidak bertumpu pada eksistensi tekstualnya. Melainkan studi tentang fenomena sosial yang lahir terkait dengan kehadiran al-Qur'an dalam wilayah geografi tertentu dan mungkin masa tertentu pula." ${ }^{\prime 9}$

Menawarkan The Living al-Qur'an sebagai sebuah objek kajian pada dasarnya adalah menawarkan fenomena tafsir atau pemaknaan al-Qur'an dalam arti yang lebih luas daripada yang selama ini dipahami, untuk dikaji dengan menggunakan perspektif yang juga lebih luas, lebih bervariasi. Sementara itu, mengusung pemaknaan gejala sosial-budaya ke kancah sebuah perbincangan, hal itu-menurut saya-berarti menempatkan asumsiasumsi paradigma antropologi hermeneutik atau antropologi interpretif sebagai landasan pemikiran untuk menelaah dan memperbincangkan gejala tersebut. Sehubungan dengan itu, perlu kiranya dipaparkan di sini secara singkat asumsi-asumsi dasar antropologi hermeneutik sebelum kita membicarakan berbagai macam pemaknaan terhadap al-Qur'an sebagai sebuah kitab yang berisi Sabda-sabda Tuhan.

Salah satu asumsi dasar dari paradigma antropologi interpretif adalah bahwa manusia adalah animal symbolicum ${ }^{10}$ atau hewan yang mampu menggunakan, menciptakan dan mengembangkan simbol simbol untuk menyampaikan pesan dari individu satu ke individu yang lain. Simbol di sini diartikan sebagai segala sesuatu yang dimaknai, sehingga pemaknaan merupa-

${ }^{7}$ Ibid., h. 9.

8 Yusuf, M., "Pendekatan Sosiologi dalam Penelitian Living Qur'an,” dalam M. Mansyur, dkk., Metodologi Penelitian Living Qur'an dan Hadits, (Yogyakarta: TH. Press, 2007), h. 36-37.

${ }^{9}$ Ibid., h. 39.

${ }^{10}$ Lihat Cassirer, E., An Essay on Man, (New Haven: Yale University Press, 1945). 
kan proses yang sangat penting dalam kehidupan manusia. ${ }^{11}$ Kemampuan memberikan makna inilah yang membedakan manusia dengan binatang, dan membuat manusia kemudian mampu berbahasa. Bahasa merupakan sebuah sistem pemaknaan. Bahasa-sebagai perangkat simbol berupa bunyi yang diproduksi oleh mulut manusia-merupakan perangkat simbol yang paling fundamental dalam kehidupan manusia, lewat mana manusia memberikan makna terhadap dunianya. Melalui bahasa inilah manusia berinteraksi dengan manusia yang lain. Melalui bahasalah terbangun kehidupan sosial dan kebudayaan. Tanpa bahasa tidak akan ada kehidupan sosial, tidak akan ada kebudayaan. Kehidupan sosial yang menghasilkan kebudayaan hanya bisa lahir karena adanya interaksi sosial yang simbolik, dan interaksi simbolik ini hanya dapat berlangsung jika ada bahasa.

Adanya kemampuan berbahasa pada setiap manusia yang normal menunjukkan bahwa kemampuan simbolik atau kemampuan memberikan makna ini diwarisi oleh manusia secara genetis. Ini merupakan asumsi dasar kedua. Dengan kemampuan ini manusia tidak pernah lagi melihat segala sesuatu 'sebagaimana adanya', tetapi sebagai sesuatu yang telah diberi makna, karena segala sesuatu dalam kehidupan manusia selalu menjadi objek atau tujuan pemaknaannya. Pemaknaan atau pemberian makna pada dasarnya adalah kegiatan menghubungkan sesuatu-yaitu simbol itu sendiri-dengan sesuatu yang lain, yaitu maknanya, pada tataran kognisi (pikiran). Kalau kemampuan memaknai bersifat genetis, kerangka pemaknaan dan hasil pemaknaan bersifat kultural, bersifat budaya. Kemampuan melakukan pemaknaan boleh dikatakan semacam 'wadah' yang diperoleh lewat keturunan, sedang isi yang digunakan untuk memberikan, 'menempelkan' maknamakna, merupakan sesuatu yang didapat lewat kehidupan sosial, lewat proses sosialisasi dan enkulturasi. Ini adalah asumsi yang ketiga. Kemampuan berbahasa misalnya, merupakan kemampuan yang bersifat universal, yang dimiliki oleh semua manusia yang normal, tetapi bahasa yang dikuasainya merupakan sesuatu yang didapat secara kultural, diperoleh lewat proses belajar. Melalui pengetahuan yang diperoleh lewat bahasa inilah manusia memberikan pemaknaan kepada segala sesuatu, bahkan juga kepada dirinya

${ }^{11}$ Ahimsa-Putra, H.S., “Simbol, Tanda, Budaya dan Ilmu Budaya,” makalah seminar, 2002. 
sendiri. Oleh karena sifatnya yang kultural maka pemaknaan terhadap sesuatu tidak pernah bisa bersifat universal. Dia selalu terperangkap dalam sebuah wadah pemaknaan tertentu, dalam bahasa tertentu.

Dengan bekal kemampuan simbolisasi dan kerangka pemaknaan tersebut maka manusia selalu memandang dunia sekelilingnya sebagai dunia simbol, sebagai belantara simbol dengan berbagai macam maknanya. Dalam kehidupan sehari-hari simbol-simbol yang mewujudkan bahasa adalah tulisan-tulisan, yang jika terkumpul sebagai kesatuan dan menyampaikan pesan atau makna tertentu biasa disebut 'teks'. Suatu belantara simbol pada dasarnya selalu ditanggapi oleh manusia sebagai kumpulan simbol yang tersusun dengan cara tertentu dan dapat dimaknai dengan cara tertentu pula. Oleh karena kehidupan sehari-hari dan lingkungan kehidupan tersebut merupakan sebuah belantara simbol, maka kehidupan sehari-hari dan lingkungan tersebut juga merupakan sebuah "teks," yang dapat "dibaca" dan dimaknai.

Di tengah-tengah kumpulan manusia yang merupakan animal symbolicum, sebuah benda seperti Kitab al-Qur'an tidak lagi dapat hadir tanpa makna. Begitu pula perlakuan manusia terhadap al-Qur'an itu sendiri. Jika alQur'an sebagai kitab yang merupakan kumpulan, jaringan dan susunan simbol-simbol-yaitu huruf-huruf Arab—adalah sebuah teks, demikian pula halnya dengan berbagai macam perlakuan manusia terhadap al-Qur'an sebagai sebuah jaringan dan susunan simbol. Dari sudut pandang ini, The Living al-Qur'an adalah sebuah jagad simbolis, sebuah symbolic universe, dan juga sebuah teks, yang dapat dimaknai. Sebagai sebuah sistem simbol, alQur'an tidak hanya menjadi objek penafsiran para ahli tafsir, tetapi juga ditafsirkan oleh setiap Muslim, dan bahkan juga oleh mereka yang nonMuslim. Dilihat dari perspektif antropologi, setiap individu sebagai animal symbolicum adalah seorang penafsir. Masing masing individu tentu memiliki kerangka pemaknaannya sendiri, sehingga tafsir masing-masing individu adalah "benar" atau masuk akal dalam kerangka tafsir yang digunakan. Oleh karena itu pula, di sini tidak ada lagi tafsir yang dianggap paling benar. Dengan demikian setiap individu dapat belajar dari individu lain tentang tafsir-tafsir yang berbeda.

Adalah tugas peneliti kemudian untuk berusaha memahami dan memaparkan pola-pola pemaknaan terhadap al-Qur'an sebagai sebuah sistem simbol, dan menghubungkannya dengan berbagai hal di luarnya-yang me- 
rupakan konteks dari pemaknaan tersebut-, agar kemudian dapat dimengerti mengapa pemaknaan yang diberikan adalah sebagaimana yang ditemui oleh peneliti.

\section{Al-Qur'an dan Beberapa Pemaknaannya}

Jika kita perhatikan dengan seksama kehadiran al-Qur'an di tengah kehidupan umat Islam di Indonesia, maka akan terlihat adanya berbagai pemaknaan terhadap al-Qur'an sebagai sebuah kitab yang berisi Sabda-sabda Allah SWT dalam bahasa Arab, ditulis dengan huruf Arab.

Pertama, al-Qur'an dimaknai sebagai "Kitab," sebagai "Buku," sebagai "Bacaan". Ini merupakan pemaknaan yang paling umum diberikan karena secara fisik al-Qur'an memang berupa lembaran-lembaran kertas yang bertulisan ayat-ayat yang kemudian dikumpulkan menjadi satu dan disusun sedemikian rupa sehingga menjadi sebuah buku, sebuah kitab. Sebagai kitab maka al-Qur'an paling banyak tampak sebagai sesuatu yang dibaca, dan berdiri sendiri (independent).

"Dibaca" di sini bisa berarti dibaca dan disuarakan, bisa dibaca dan direnungkan isinya, bisa pula dibaca dan didiskusikan secara bersama makna kata-katanya. Jika dibaca dan disuarakan, maka akan ada orang yang berusaha membacanya dengan berlagu, dengan suara yang merdu. Dari upayaupaya untuk memperindah bacaan inilah kemudian muncul tradisi lomba baca al-Qur'an seperti yang berlangsung di Indonesia sampai sekarang. Jika dibaca dan direnungkan isinya, maka yang lebih banyak dilakukan adalah dengan membaca sendirian dan pelan-pelan. Orang tidak membacanya dengan bersuara. Jika dibaca dan didiskusikan makna kata-katanya, maka yang dilakukan adalah beberapa orang duduk berkeliling dan salah seorang yang di antara mereka, yang paling mengerti bahasa Arab dan makna ayatayat al-Qur'an akan memimpin dan membimbing diskusi tersebut. Dari sinilah muncul berbagai kegiatan pengajian seperti biasa kita lihat di masjidmasjid di Indonesia.

Al-Qur'an sebagai kitab adalah pemaknaan utama yang menjadi dasar dari kegiatan mempelajari al-Qur'an sebagaimana terlihat di pondok-pondok pesantren, di sekolah-sekolah serta di berbagai perguruan tinggi seperti Universitas Islam Negeri di Indonesia. Oleh karena al-Qur'an merupakan kitab yang berisi firman-firman Allah SWT dengan bahasa Arab yang tidak 
selalu jelas maknanya bagi manusia, bahkan juga bagi mereka yang mampu berbahasa Arab, maka upaya memahami dan memaknai firman-firman tersebut tentu tidak dapat dilakukan seenaknya. Diperlukan keahlian-keahlian khusus untuk dapat mengetahui makna firman-firman tersebut supaya firman-firman tersebut tidak "disalahgunakan" oleh mereka yang mempunyai kepentingan-kepentingan tertentu yang berlawanan dengan ajaran-ajaran dalam al-Qur'an itu sendiri, atau supaya ayat-ayat tersebut tidak disalahpahami, yang kemudian dapat menyebabkan munculnya perilaku-perilaku atau kegiatan yang "tidak sesuai" dengan apa yang dimaksudkan oleh Sabdasabda Tuhan dalam al-Qur'an tersebut.

Kedua, al-Qur'an dimaknai sebagai sebuah kitab yang istimewa, sebagai kitab suci yang bahkan dalam menyimpannya orang tidak boleh melakukannya seenaknya atau menyamakannya dengan kitab-kitab biasa yang lain. AlQur'an bukan kitab biasa karena berisi sabda-sabda Allah SWT yang diturunkan lewat malaikat Jibril, lewat tanda-tanda tertentu, lewat cara-cara tertentu yang khusus, dan sebagainya. Allah SWT merupakan Dzat Yang Mahasuci, Subhānallāh, Mahasuci Allah. Oleh karena itu, firman-firman-Nya juga suci sifatnya.

Keistimewaan al-Qur'an ini begitu banyak, dan belum semuanya berhasil diketahui oleh manusia. Saya yakin bahwa al-Qur'an mengandung begitu banyak hal, begitu banyak keistimewaan, dan hanya sebagian kecil saja yang telah diketahui oleh manusia. Beberapa hal yang telah diketahui misalnya adalah keindahan isi ayat-ayat al-Qur'an (terutama bagi mereka yang dapat menangkap dan memahami keindahan ini). Keindahan ini bisa terletak pada susunan kalimat-kalimatnya, pada kata-katanya, pada persamaan dan perbedaan bunyi akhir kata-kata, yang memperlihatkan keteraturan atau polapola tertentu, bisa pula pada aspek-aspek yang lain.

Ketiga, al-Qur'an sebagai kumpulan petunjuk. Dalam surat al-Baqarah ayat 2, Allah SWT berfirman "Dhālika 'l-kitābu lā raiba fihi hudal li 'l-muttaqīn, kitab (al-Qur'an) ini tidak ada keraguan di dalamnya, menjadi petunjuk bagi orang-orang yang bertaqwa". Ayat ini dengan jelas dan tegas mengatakan bahwa al-Qur'an adalah kitab yang berisi petunjuk. Petunjuk adalah segala sesuatu yang dapat membawa manusia kepada sesuatu yang baik atau yang membuat seorang individu sampai pada suatu keadaan yang baik dan benar. Kalau dia tidak membawa manusia pada keadaan tersebut maka dia 
dikatakan sebagai "penyesat" atau yang menyesatkan, yaitu segala sesuatu yang membuat seseorang tidak sampai pada keadaan yang dianggap baik dan benar, atau yang diinginkan.

Berbagai petunjuk memang dapat kita temukan dalam al-Qur'an. Mulai dari hal-hal yang dalam pandangan manusia terlihat begitu sederhana dan sepele (tetapi sama sekali tidak sepele dalam pandangan Allah SWT), hingga ke hal-hal yang memang dipandang oleh manusia begitu penting. Ayat-ayat al-Qur'an berisi petunjuk-petunjuk yang berupa perintah, larangan dan anjuran, dengan tingkat kepentingan yang berbeda-beda, sehingga ada yang dikatakan sebagai wajib, sunnat, dan sebagainya. Mereka yang meyakini alQur'an sebagai petunjuk dari Allah Yang Maha Kuasa, Penguasa langit dan bumi, Pencipta alam semesta, akan selalu mencari petunjuk-petunjuk dari alQur'an ketika mereka menghadapi berbagai masalah dalam kehidupan mereka. Dengan mengikuti petunjuk-petunjuk ini mereka kemudian akan dapat mengatasi masalah-masalah tersebut. Di sini al-Qur'an kemudian juga dapat menjadi semacam penghibur. Dari sini lahirlah pemaknaan berikutnya, yakni al-Qur'an sebagai 'obat hati'.

Keempat, banyak orang memaknai al-Qur'an sebagai "Tombo Ati" (obat hati) untuk mengobati hati mereka yang sedang sedih. Pemaknaan seperti ini memang sudah sangat umum. Seseorang yang tengah sedih mungkin akan dapat terhibur hatinya manakala dia membaca ayat 5-6 dari surat al-Insyirah yang berbunyi "Fa inna ma'a 'l-'usri yusrā, inna ma'a 'l-'usri yusrā" (maka sesungguhnya beserta kesukaran ada kemudahan; sesungguhnya beserta kesukaran ada kemudahan). Melalui ayat ini Allah SWT menjanjikan bahwa kesukaran atau musibah yang dialami oleh seseorang tidak akan berlangsung selamanya. Setelah mengalami kesukaran, orang kemudian akan mendapatkan kemudahan, sehingga dia tidak perlu merasa sedih atas kesulitan yang dialaminya. Banyak sekali ayat-ayat dalam al-Qur'an yang bersifat menghibur karena di situ Allah SWT menyatakan janjinya kepada golongan manusia tertentu, yakni mereka yang beriman, yang sabar, yang selalu taat dan banyak mengingat Allah, bahwa mereka akan mendapatkan imbalan yang jauh lebih baik, lebih banyak, lebih menyenangkan dari Allah SWT atas ketaatan mereka dalam menjalankan perintah Allah dan menjauhi larangan-larangan-Nya. Mereka yang miskin atau selalu hidup dalam kekurangan, kesedihan, namun tetap bersabar dan beriman, akan mendapat ganti kehidupan yang lebih baik 
dan jauh lebih nyaman dalam kehidupan sesudah mati. Mereka akan ditempatkan di surga, sebuah tempat yang penuh dengan kenikmatan dan kesenangan yang bersifat abadi. Apa yang ada di dalamnya tidak pernah terbayangkan atau terpikirkan oleh manusia dalam hal keindahan dan kenikmatannya.

Kelima, al-Qur'an merupakan tombo awak (obat jasmani). "Barangsiapa membaca surat al-Ikhlas dalam keadaan lapar maka akan menjadi kenyang dan jika dalam keadaan dahaga maka ia dapat menjadi segar."12 Terlepas dari status hadits ini-mungkin sebagian orang akan menganggapnya sebagai hadits da'if-hadits ini paling tidak memberikan keterangan kepada kita bahwa sebagian umat Islam yakin betul bahwa ayat-ayat al-Qur'an memang dapat menjadi obat bagi tubuh yang lemah atau sakit.

Kita tentu pernah membaca sebuah kisah di masa Rasulullah SAW masih hidup, yang menceriterakan beberapa orang sahabat Rasulullah yang pulang dari bepergian dan kebetulan melewati sebuah kaum yang ketua sukunya sedang jatuh sakit. Wakil kaum ini meminta para sahabat untuk menyembuhkan dan berjanji akan memberikan imbalan yang layak. Para sahabat setuju. Salah seorang kemudian maju untuk menyembuhkan sakit si kepala suku dengan membacakan surat al-Fatihah, dan ternyata si sakit kemudian sembuh, dan mereka mendapat upah berupa kambing.

Dua kisah di atas sudah cukup kiranya untuk mengingatkan bahwa ayatayat atau surat-surat dalam al-Qur'an memang memiliki kekuatan untuk menyembuhkan kembali tubuh yang sakit, dan tidak sedikit orang Islam yang meyakininya, walaupun mungkin belum pernah mengalaminya atau membuktikannya secara langsung. Banyak yang mengira bahwa kemampuan ayat atau surat dalam al-Qur'an tersebut hanya dapat diaktifkan oleh orang-orang tertentu saja yang dianggap mempunyai kedekatan dengan Allah atau memiliki hubungan khusus dengan Allah SWT.

Keenam, al-Qur'an dimaknai sebagai sarana perlindungan. Sebagai firman Allah SWT, ayat-ayat atau surat-surat tertentu dalam al-Qur'an diyakini dapat menjadi sarana untuk memperoleh perlindungan dari Allah. Perlindungan ini tidak hanya dari bahaya dalam kehidupan di dunia ini, tetapi

12 Umar, M.A.C., Khasiat dan Fadlilah al-Ikhlas, (Semarang: Toha Putra, 1979b). 
juga dari bahaya atau malapetaka yang bakal menimpa seseorang setelah dia mati nanti.

1. Perlindungan terhadap bahaya alam. Berkata 'Uqbah ibn 'Amir: "Ketika saya berjalan bersama-sama dengan Rasulullah SAW di antara Juhfah dan Abwa, tiba-tiba kami diserang oleh angin kencang dan gelap yang amat sangat. Maka Rasulullah berlindung kepada Tuhan dengan membaca a'ūdzu birabbi 'I-falaq dan a'ūdzu birabbi 'n-nās, dan beliau bersabda kepadaku: "Wahai 'Uqbah berlindung pulalah engkau kepada Tuhan dengan membaca kedua surat itu, karena tidak ada suatu pun perlindungan yang lebih baik dari kedua-duanya". Berkata pula "Uqbah: "Dan aku sering mendengar Nabi mengimami kami dalam shalat dengan membaca kedua surat itu" (HR. Abu Dawud). ${ }^{13}$

Hadits ini dengan jelas menyatakan bahwa menurut Nabi Muhammad SAW surat al-Falaq dan al-Nas yang terdapat di bagian akhir al-Qur'an jika dibaca dapat membuat pembacanya memperoleh perlindungan dari bahaya-bahaya yang begitu nyata, yang dialami ketika seseorang masih hidup.

2. Perlindungan terhadap gangguan syaithan (setan) atau makhluk halus yang jahat. Lebih dari itu, ayat-ayat tertentu dalam al-Qur'an juga diyakini dapat memberikan perlindungan kepada pembacanya dari gangguan atau kejahatan makhluk-makhluk halus, seperti misalnya ayat Kursi. Mengenai hal ini tentu kita pernah membaca sebuah hadits yang cukup panjang yang menceriterakan tentang salah seorang sahabat Rasulullah SAW yakni Abu Hurairah ra., yang ditugaskan untuk menjaga harta zakat umat Islam. Selama dua malam berturut-turut Abu Hurairah berhasil menangkap si pencuri harta, namun setiap kali tertangkap pencuri ini selalu meminta belas-kasihan untuk tidak dilaporkan kepada Rasulullah SAW karena dia orang miskin, dan dia selalu berjanji untuk tidak datang mencuri lagi. Meskipun demikian, usaha pencurian ini tetap dilakukannya, sampai pada malam ketiga si pencuri tertangkap kembali dan minta dilepaskan. Dia berjanji akan memberitahu sahabat tersebut sesuatu hal yang akan bermanfaat untuknya. Ketika dilepas pencuri ini

13 Ibid. 
mengatakan bahwa kalau seseorang membaca ayat Kursi sebelum tidur dia akan mendapat perlindungan dari kejahatan setan.

3. Perlindungan terhadap siksa setelah kematian. Banyak bahkan mungkin semua umat Islam percaya bahwa ayat-ayat atau surat-surat tertentu dalam al-Qur'an dapat memberikan perlindungan kepada pembacanya dari siksa yang mungkin diterima di alam kubur. Surat yang dikenal dapat memberikan perlindungan dari siksa kubur kepada orang yang rajin membacanya adalah surat al-Mulk. Sahabat Abdullah bin 'Abbas berkata bahwa Rasulullah SAW telah bersabda, "Sungguh di dalam alQur'an aku dapati ada sebuah surat berisi tiga puluh ayat. Siapa yang membacanya di saat ia akan tidur, maka dengan itu ditulis baginya tiga puluh kebaikan, dihapus tiga puluh kesalahan darinya, diangkat untuknya sampai tiga puluh derajat, serta Allah SWT mengutus satu di antara para malaikat agar menghamparkan sayap atasnya, menjaganya dari (gangguan) segala sesuatu sampai ia bangun tidur. Itulah surat yang mengajukan gugatan membela orang yang senantiasa membacanya kelak di alam kubur, yakni surat Tabārak."14

Ketujuh, al-Qur'an sebagai Sumber Pengetahuan. Sebagai sebuah kitab yang berisi tidak hanya petunjuk, perintah, larangan dan anjuran, tetapi juga berisi berbagai ceritera mengenai peristiwa-peristiwa yang pernah terjadi di masa lampau, al-Qur'an juga dapat dipandang sebagai sumber informasi atau sumber pengetahuan, dan kalau kitab ini diyakini berasal dari Allah SWT, Pencipta langit dan bumi dengan segala isinya, maka tentunya informasi yang ada di dalamnya semuanya benar belaka. Tidak ada yang salah sama sekali. Dengan demikian kisah-kisah sejarah yang ada dalam al-Qur'an merupakan kisah sejarah yang paling dapat dipercaya, karena tidak berasal dari manusia, tetapi dari Penggerak dan Pencipta peristiwa-peristiwa sejarah itu sendiri. Demikian pula halnya dengan berbagai firman Allah SWT yang menyatakan tentang keadaan yang akan dialami oleh manusia di masa mendatang, ketika dunia dengan segala isinya tiba pada hari kehancurannya, Hari Kiamat.

Kedelapan, al-Qur'an sebagai Sumber Pengetahuan Masa Lampau. Dalam al-Qur'an dapat kita ketemukan berbagai kisah kehidupan manusia di masa

14 Badri, Y., Surat Tabaarak: Pendinding dari Siksa Kubur, alih bahasa oleh H. Nurullah dan F. Fauzan, (Surabaya: Aneka Pustaka Islam, 1991), h. 41-42.

Walisongo, Volume 20, Nomor 1, Mei 2012 
lampau, terutama kisah-kisah mengenai salah satu episode dalam kehidupan para nabi yang telah diutus oleh Allah SWT yang oleh Allah perlu disampaikan kepada umat manusia, khususnya kepada umat Islam untuk dapat dijadikan contoh atau pelajaran. Di situ kita temukan kisah Nabi Nuh as. dengan perahunya, kisah Nabi Yusuf as. dengan kakak-kakak dan adiknya, kisah Nabi Sulaiman as., kisah Nabi Adam as. ketika berada di surga dan kemudian diturunkan ke bumi, dan masih banyak kisah-kisah lain yang juga penting, seperti kisah para penghuni gua dengan anjingnya, kisah pembunuhan di kalangan Bani Israil, kisah Maryam, dan seterusnya. Dengan sebagian isi yang seperti itu al-Qur'an se-bagai kitab juga merupakan sebuah sumber pengetahuan mengenai beberapa episode penting sejarah kehidupan manusia di masa lampau. Bagi sementara orang, dalam kedudukan seperti itu al-Qur'an lebih dapat dipercaya, diyakini kebenarannya, daripada kitab-kitab yang berisi kisah-kisah sejarah yang ditulis oleh manusia, karena al-Qur'an berasal dari Tuhan sendiri, yang merupakan Sang Maha Pencipta.

Kesembilan, al-Qur'an sebagai Sumber Pengetahuan Masa Kini. Sebagian isi dari al-Qur'an juga merupakan keterangan-keterangan mengenai kehidupan manusia yang tengah berlangsung di masa kini. Ini terutama berkenaan dengan sifat-sifat manusia yang umum, mengenai hal-hal yang harus atau sebaiknya dilakukan oleh manusia di masa sekarang untuk memperoleh keberuntungan abadi di masa yang akan datang. Dalam konteks masa kini, informasi yang perlu dicari dalam al-Qur'an terutama adalah informasi mengenai hal-hal yang harus dilakukan, sebaiknya dilakukan atau tidak boleh dilakukan sama sekali dalam kehidupan bermasyarakat. Jadi pengetahuan di sini adalah pengetahuan yang menyangkut aturan-aturan, hukum-hukum tentang apa yang sebaiknya segera dilaksanakan oleh umat Islam jika mereka juga ingin menjadi umat yang selamat dalam kehidupan di dunia maupun di akhirat.

Kesepuluh, al-Qur'an sebagai Sumber Pengetahuan Masa Depan. 'Masa depan' di sini bukan hanya dalam arti tahun-tahun yang akan datang, tetapi lebih jauh dari itu, yakni kehidupan sesudah mati. Bagi mereka yang percaya betul-betul terhadap apa-apa yang ada dalam al-Qur'an, sebagian isi al-Qur'an merupakan pengetahuan mengenai hal-hal yang akan menimpa manusia, tidak hanya dalam kehidupan di dunia saja, tetapi juga kehidupan di alam kubur dan alam akhirat, yang merupakan alam yang akan dimasuki oleh 
manusia setelah dia mati. Keyakinan akan adanya kehidupan sesudah mati, yang keadaannya berkorelasi dengan perilaku seseorang semasa hidup di dunia, telah membuat penganut ajaran-ajaran dalam al-Qur'an kemudian berusaha keras untuk menjalankan perintah dan menjauhi larangan yang disebutkan dalam al-Qur'an. Di sini al-Qur'an merupakan sumber pengetahuan tentang kehidupan masa depan, kehidupan sesudah mati, yang dapat sangat mempengaruhi kehidupan manusia di dunia di masa kini.

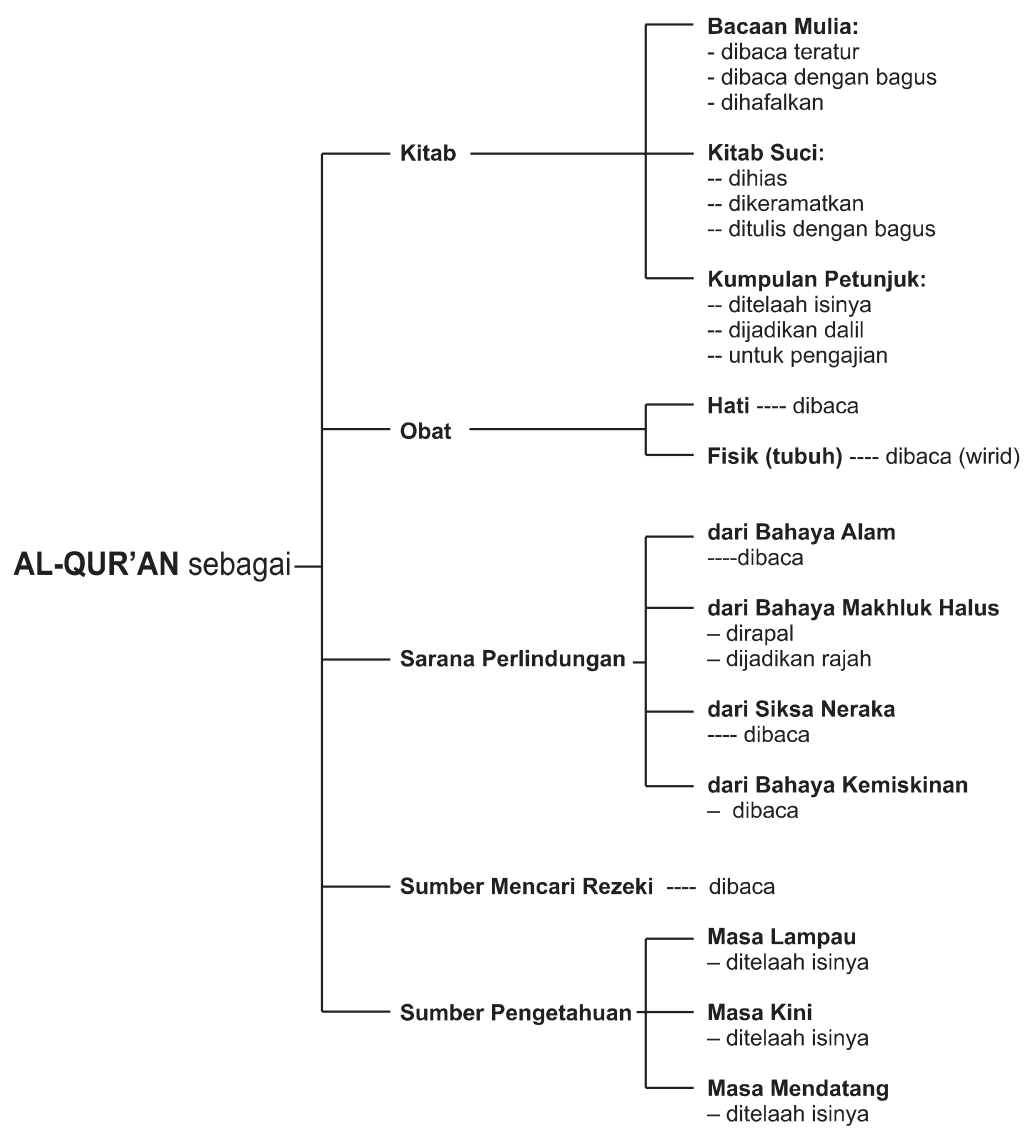

Gambar 1.

Pemaknaan al-Qur'an oleh Masyarakat

Walisongo, Volume 20, Nomor 1, Mei 2012 
Masih ada lagi berbagai pemaknaan al-Qur'an lainnya, yang tidak semuanya dapat dipaparkan satu persatu di sini, karena akan membuat tulisan ini sangat panjang. Skema di atas menggambarkan berbagai pemaknaan alQur'an yang selama ini telah kita ketahui. Skema ini masih dapat dikembangkan lagi dengan melakukan penelitian-penelitian yang lebih mendalam tentang bagaimana masyarakat memperlakukan al-Qur'an atau ayat-ayat yang terdapat di dalamnya. Dengan mengembangkan skema ini hingga menjadi sebuah skema yang komprehensif, akan dapat diketahui makna-makna apa saja dan pola-pola perlakuan apa yang diberikan oleh umat Islam (dan mungkin juga yang non-Islam) terhadap al-Qur'an sebagai sebuah kitab. Skema ini juga merupakan peta pandangan orang terhadap al-Qur'an, yang akan sangat bermanfaat bagi mereka yang bermaksud mengembangkan Islam dan "membumikan" al-Qur'an.

\section{The Living al-Qur'an: Fenomena Sosial-Budaya}

Berbagai pemaknaan al-Qur'an dan perwujudannya dalam kehidupan sehari-hari merupakan peristiwa atau gejala sosial-budaya yang biasa mendapat perhatian dari para ahli antropologi agama dan ahli sosiologi agama. Di Indonesia fenomena semacam ini setahu saya belum banyak memperoleh perhatian dari para pakar di perguruan-perguruan tinggi Islam baik yang swasta maupun negeri, karena dalam kajian-kajian Islam di perguruan tinggi yang menjadi pusat kajian adalah kitab al-Qur'an itu sendiri, bukan al-Qur'an sebagaimana dia dipahami, ditafsir dan digunakan dalam kehidupan sehari-hari oleh sebuah komunitas atau suatu masyarakat.

Memandang The Living al-Qur'an atau "al-Qur'an yang hidup" secara antropologis pada dasarnya adalah memandang fenomena ini sebagai fenomena sosial-budaya, yakni sebagai sebuah gejala yang berupa pola-pola perilaku individu-individu yang muncul dari dasar pemahaman mereka mengenai al-Qur'an. Dengan perspektif ini fenomena yang kemudian menjadi objek kajian bukan lagi al-Qur'an sebagai kitab tetapi perlakuan manusia terhadap al-Qur'an dan bagaimana pola-pola perilaku yang dianggap berdasarkan atas pemahaman tentang al-Qur'an itu diwujudkan. Objek kajian di sini adalah bagaimana berbagai pemaknaan terhadap al-Qur'an di atas hadir, dipraktekkan dan berlangsung dalam kehidupan sehari-hari manusia. 
Al-Qur'an yang hidup di tengah kehidupan sehari-hari manusia bisa mewujud dalam bentuk yang beraneka-ragam, yang bagi sebagian pemeluk Islam mungkin malah telah dianggap menyimpang dari ajaran-ajaran dasar dalam agama Islam itu sendiri. Kajian The Living al-Qur'an di sini kemudian memang lebih dekat dengan kajian-kajian ilmu sosial-budaya seperti antropologi dan sosiologi, di mana peneliti tidak lagi mempersoalkan kebenaran sebuah tafsir atau perlakuan terhadap al-Qur'an, karena tujuan penelitian bukanlah 'mengadili' atau 'menilai' sebuah pemaknaan dan pengejawantahannya dalam kehidupan, tetapi memahami, memaparkan dan menjelaskan gejala-gejala tersebut sebaik-baiknya.

Fenomena living al-Qur'an juga dapat dikatakan sebagai "qur'anisasi" kehidupan, yang artinya memasukkan al-Qur'an-sebagaimana al-Qur'an tersebut dipahami-ke dalam semua aspek kehidupan manusia, atau menjadikan kehidupan manusia sebagai suatu arena untuk mewujudnyaal-Qur'an di bumi. Al-Qur'anisasi kehidupan manusia dapat berupa penggunaan ayatayat dalam al-Qur'an yang diyakini sebagai mempunyai 'kekuatan ghaib' tertentu untuk mencapai tujuan tertentu, misalnya membuat seseorang menjadi terlihat 'sakti' karena tidak dapat dilukai dengan senjata tajam manapun. Ayat-ayat al-Qur'an di sini memang tidak lagi terlihat sebagai "petunjuk," perintah, larangan melakukan sesuatu atau ceritera mengenai sesuatu, tetapi lebih tampak sebagai 'mantra' yang jika dibaca berulang-kali sampai mencapai jumlah tertentu akan dapat memberikan hasil-hasil tertentu seperti yang diinginkan.

Qur'anisasi kehidupan tersebut juga dapat berupa praktek-praktek pengobatan dengan menggunakan ayat-ayat tertentu dalam al-Qur'an sebagaimana pernah dipraktekkan oleh sebagian sahabat Nabi di masa lampau. Bagi sebagian orang praktek-praktek semacam ini dianggap sah- sah saja, karena memang ada contohnya di masa Rasulullah SAW masih hidup, bahkan—setahu saya-tidak ada pernyataan Rasulullah yang secara eskplisit melarang praktek-praktek semacam itu. Sementara bagi yang lain praktekpraktek semacam itu lebih mendekati praktek 'perdukunan'-yang tidak 'rasional' - yang biasanya kemudian diasosiasikan dengan 'kemusyrikan' dan karena itu kemudian dijauhi atau malah dilarang sama sekali.

Dalam konteks kajian qur'anisasi kehidupan manusia, memperlakukan dan mempelajari al-Qur'an sebagai sebuah kitab yang berisi petunjuk- 
petunjuk—sebagaimana dilakukan di sekolah-sekolah dan institusi pendidikan Islam-tidak lagi dipandang sebagai satu-satunya aktivitas atau perlakuan yang paling 'tepat' terhadap al-Qur'an. Pemaknaan dan perlakuan semacam itu hanya dipandang sebagai salah satu bentuk perlakuan yang dapat diberikan terhadap al-Qur'an, dan pemaknaan serta perlakuan inilah yang kemudian menjadi objek kajian itu sendiri. Tentu saja, peran dan kedudukan al-Qur'an sebagai kitab di situ juga tidak dapat diabaikan. Namun, yang dimaksud dengan "al-Qur'an" di sini bukan lagi hanya kitabnya, tetapi juga tafsir dan pola-pola perilaku yang didasarkan pada tafsir atas ayat-ayat dalam al-Qur'an tersebut.

Dengan menggunakan perspektif semacam ini maka objek material dalam kajian The Living al-Qur'an mencakup antara lain berbagai macam pemaknaan al-Qur'an di atas dan perwujudan pemaknaan-pemaknaan tersebut dalam kehidupan sehari-hari. Di sini kajian hukum-hukum yang ada dalam al-Qur'an misalnya, bukan lagi kajian yang hanya memusatkan perhatian pada teks-teks hukumnya tetapi juga penafsiran terhadap hukumhukum tersebut oleh tokoh-tokoh dan warga masyarakat, yang biasanya akan sangat dipengaruhi oleh budaya-budaya lokal yang mereka anut, serta praktek-praktek sosial yang didasarkan pada tafsir-tafsir yang diberikan. Beberapa contoh konkret living al-Qur'an sebagai gejala sosial budaya misalnya adalah seorang pengemis buta atau pengemis-pengemis sejenisnya yang membaca ayat-ayat al-Qur'an sambil menengadahkan tangan minta sedekah dari penumpang bus, penumpang kereta api, atau orang-orang yang lalulalang di sebuah jalan. Ini me-rupakan sebuah fenomena sosial, karena yang melakukan hal ini tidak hanya satu orang, dan orang-orang lain yang tidak melakukannya memberikan reaksi yang berbeda-beda terhadap fenomena tersebut.

Apa yang perlu kita teliti dari gejala tersebut? Biasanya di sini peneliti ingin mengetahui bagaimana pandangan si pelaku atas apa yang dilakukannya. Peneliti akan mencoba mengetahui pandangan pengemis tersebut mengenai mengemis sambil membacakan ayat-ayat al-Qur'an. Oleh karena pandangan ini sedikit-banyak juga dibentuk oleh pengalaman pribadinya, maka peneliti kemudian perlu mengetahui beberapa bagian sejarah kehidupan pribadi pengemis tersebut yang relevan dengan kegiatannya mengemis.

Contoh lain adalah kegiatan Yasinan, yaitu pembacaan surat Yasin pada malam Jum'at oleh kelompok-kelompok pengajian tertentu, atau mem- 
bacanya di rumah seseorang yang salah seorang anggota keluarganya telah meninggal, baik itu yang baru saja meninggal ataupun yang sudah beberapa tahun sebelumnya. Kegiatan semacam ini dapat diteliti untuk dibandingkan dan kemudian dipahami fungsi-fungsi sosial-kultu-ralnya, seperti halnya kajian mengenai fungsi rituil dalam antropologi budaya; atau diteliti pandangan orang-orang yang melakukan ritual itu mengenai surat yang mereka baca, tentang pembacaan surat Yasin yang berlangsung pada malam Jum'at, dan sebagainya.

Kegiatan dzikir bersama dengan membaca surat-surat tertentu dalam alQur'an beberapa kali, yang rutin dilakukan setiap minggu juga merupakan salah satu bentuk Living al-Qur'an yang dapat diteliti. Di sini peneliti dapat mengarahkan perhatian pada ayat-ayat yang dibaca dan pemaknaan dari mereka yang melakukan dzikir bersama, dan kemudian mencoba menentukan hubungan antara pemaknaan tersebut dengan kegiatan dzikir bersama yang mereka lakukan.

Wujud Living al-Qur'an yang lain adalah penulisan ayat-ayat al-Qur'an menjadi seni kaligrafi atau lukisan kaligrafis. Di sini peneliti dapat mengarahkan perhatiannya pada pemaknaan yang diberikan oleh penulis dan pelukis kaligrafi, atau pada pembeli-pembeli tulisan dan lukisan tersebut. Termasuk juga penempatan tulisan dan lukisan tersebut di rumah-rumah para pembeli, karena di situ juga tersirat pemaknaan tertentu dari pembeli atas tulisan dan lukisan yang berisi ayat-ayat al-Qur'an tersebut.

\section{E. The Living al-Qur'an: Paradigma untuk Mempelajarinya}

Dengan menempatkan pemaknaan al-Qur'an dan perwujudannya dalam kehidupan sehari-hari manusia sebagai titik pusat kajian, maka paradigmaparadigma yang diperlukan di sini tidak lagi sama dengan paradigma yang digunakan untuk mengkaji al-Qur'an sebagai sebuah kitab. Memang kita masih dapat menggunakan paradigma hermeneutik di sini, karena interpretasi masih tetap dilakukan terhadap gejala-gejala sosial-budaya bilamana kita memandang gejala-gejala tersebut sebagai "teks". Akan tetapi karena "teks" di sini merupakan sebuah model atau metafor, dan "teks" yang sebenarnya adalah "pemaknaan al-Qur'an dan perwujudannya dalam kehidupan," maka hermeneutik yang dilakukan tidak lagi sama dengan hermeneutik dalam kajian teks yang sebenarnya. 
Banyak paradigma antropologi yang dapat digunakan untuk mempelajari The Living al-Qur'an, namun tidak semua paradigma ini dapat diterapkan dengan mudah di Indonesia, karena terbatasnya kepustakaan yang tersedia. Dari sekian banyak paradigma tersebut, paradigma yang saya pandang dapat dipakai dan dapat memberikan hasil yang memuaskan jika diterapkan dengan baik adalah beberapa paradigma berikut.

\section{Paradigma Akulturasi}

Akulturasi adalah sebuah proses yang terjadi ketika suatu kebudayaan bertemu dengan kebudayaan lain, dan kemudian mengambil sejumlah unsurunsur budaya baru tersebut serta mengubahnya sedemikian rupa sehingga unsur-unsur budaya baru tersebut terlihat seperti unsur budayanya sendiri. Dengan sudut pandang akulturasi ini seorang peneliti fenomena The Living alQur'an akan mencoba mengetahui misalnya proses dan hasil interaksi antara ajaran-ajaran yang ada dalam al-Qur'an dengan sistem kepercayaan atau budaya lokal suatu masyarakat. Peneliti akan berupaya mengetahui unsurunsur mana dari budaya lokal yang mempengaruhi pola interpretasi atau pemahaman terhadap al-Qur'an sebagai firman-firman dari Allah SWT dalam bahasa Arab, yang artinya tidak dimengerti sepenuhnya oleh masyarakat pendukung budaya tersebut, dan bagaimana ajaran-ajaran dalam al-Qur'an kemudian mengubah unsur-unsur tertentu dari budaya lokal.

Proses akulturasi ini bisa berjalan dengan lancar dan mulus, bisa juga tidak. Dalam hal ini peneliti juga dapat memperhatikan individu-individu mana yang menyebarkan unsur-unsur tertentu dari al-Qur'an, individuindividu mana yang menyebarkan unsur yang lain; tafsir mereka mengenai budaya lokal; pemanfaatan mereka atas unsur-unsur budaya lokal untuk penyebaran al-Qur'an, bahkan juga konflik-konflik yang harus mereka hadapi dalam proses penyebaran tersebut. Juga dapat diteliti, perubahan-perubahan apa yang dilakukan terhadap unsur-unsur yang ada dalam al-Qur'an, sehingga unsur-unsur tersebut lantas terlihat sebagai bagian dari budaya lokal, dan apa reaksi orang terhadap perubahan-perubahan tersebut.

\section{Paradigma Fungsional}

Paradigma fungsional digunakan ketika seorang peneliti bermaksud mengetahui fungsi-fungsi dari suatu gejala sosial budaya. Fungsi ini bisa merupa- 
kan fungsi sosial atau fungsi kultural gejala tersebut, seperti misalnya pola-pola perilaku yang muncul dari pemaknaan-pemaknaan tertentu terhadap ayat-ayat al-Qur'an. Misalnya saja pemaknaan terhadap surat-surat dan ayat-ayat tertentu, yang kemudian melahirkan pola-pola perilaku tertentu dengan fungsi sosio-kultural tertentu pula. Ketika peneliti tertarik pada fungsi budaya dari qur'anisasi kehidupan masyarakat, dia akan mengarahkan perhatiannya pada fungsi qur'anisasi tersebut pada tataran pandangan hidup, nilai-nilai, norma dan aturan yang berlaku dalam masyarakat. Jika dia tertarik pada fungsi sosial fenomena tersebut, dia akan mengarahkan perhatiannya pada fungsi-fungsi qur'anisasi terhadap interaksi, relasi dan jaringan sosial, serta pengelompokan dan pelapisan sosial yang ada di situ.

Peneliti juga dapat mencoba mengungkap fungsi-fungsi sosio-kultural dari al-Qur'an itu sendiri, yang mungkin sangat berbeda dengan fungsi alQur'an dalam konteks aktivitas belajar-mengajar di sebuah perguruan tinggi seperti UIN Sunan Kalijaga misalnya. Dalam hal ini ayat-ayat yang diyakini memiliki khasiat tertentu biasanya akan mendapat perlakuan berbeda dengan ayat-ayat yang lain. Ayat-ayat ini mungkin tidak akan dihafal, tetapi ditulis pada secarik kain putih dengan minyak misik atau za'faran, atau ditulis di atas sebuah piring, kemudian disiram dengan air dan diminum. Fungsi ayat-ayat tertentu dari al-Qur'an di sini sudah berbeda dengan fungsi ayat tersebut menurut pandangan para mahasiswa di perguruan tinggi Islam.

\section{Paradigma Struktural}

Tujuan utama seorang peneliti yang menggunakan pendekatan struktural adalah mengungkap struktur yang ada di balik gejala-gejala sosialbudaya yang dipelajari atau membangun sebuah model-yang juga merupakan struktur-yang akan dapat membuat peneliti memahami dan menjelaskan gejala-gejala yang dipelajari. Dengan menggunakan paradigma ini seorang peneliti akan mencoba memahami gejala pemaknaan al-Qur'an lewat model-model struktural tertentu.

Lewat kacamata struktural seorang peneliti dimungkinkan untuk memandang berbagai fenomena pemaknaan al-Qur'an sebagai serangkaian transformasi dari suatu struktur tertentu. Di sini al-Qur'an sebagai kitab akan dipandang sebagai salah satu perwujudan di antara sejumlah perwujudan lain (seperti misalnya ritual, mitos) dari struktur tertentu yang lebih abstrak, yang 
lebih dalam, yang seolah-olah ada "di balik" al-Qur'an. Al-Qur'an sebagai sebuah kitab di sini lantas terlihat sebagai transformasi dari al-Qur'an yang dipraktekkan dalam kehidupan sehari-hari. Dalam hal ini pada akhirnya peneliti harus dapat menampilkan sebuah model tertentu dan memperlihatkan transformasi-transformasi yang terjadi. Penelitian dapat dimulai dari aspek budaya yang mana saja. Bisa dari aspek rituil, bisa dari aspek pemaknaan, bisa dari aspek al-Qur'annya, bisa pula dari aspek budaya materialnya.

\section{Paradigma Fenomenologi}

Ketika seorang peneliti menggunakan paradigma feno-menologi untuk mempelajari suatu gejala sosial-budaya dia akan berusaha mengungkap kesadaran atau pengetahuan pelaku mengenai 'dunia' tempat mereka berada, kesadaran mereka mengenai perilaku-perilaku mereka sendiri. Hal ini dipandang sangat penting karena pemahaman atau pengetahuan mengenai 'dunia' inilah yang dianggap sebagai dasar bagi pewujudan pola-pola perilaku manusia dalam kehidupan sehari-hari. Dengan memahami 'pandangan dunia' atau 'pandangan hidup' ini peneliti kemudian akan dapat 'mengerti' mengapa polapola perilaku tertentu diwujudkan, dan bukan perilaku-perilaku yang lain.

Dengan perspektif fenomenologis ini peneliti tidak lagi akan menilai kebenaran atau kesalahan pemahaman para pelaku tertentu mengenai alQur'an, karena yang dianggap penting bukan lagi benar-salahnya sebuah tafsir atau pemahaman, tetapi isi tafsir itu sendiri. Isi tafsir inilah yang menjadi dasar dari pola-pola perilaku tertentu. Di sini peneliti dapat mencoba mengungkap misalnya pandangan masyarakat mengenai surat Yasin yang menjadi tonggak utama ritual Yasinan, atau pandangan mereka mengenai pengobatan dengan menggunakan ayat-ayat al-Qur'an, pandangan mereka mengenai kedudukan surat-surat atau ayat-ayat tertentu dalam kehidupan mereka sehari-hari, dan sebagainya.

\section{Paradigma Hermeneutik (Interpretative)}

Yang dimaksud dengan paradigma hermeneutik di sini berbeda dengan hermeneutik dalam kajian teks, karena 'teks' di sini bukan lagi sesuatu yang tertulis tetapi gejala sosial-budaya itu sendiri. Dalam artian tertentu gejala sosial-budaya memang dapat dikatakan sebagai teks, sebab gejala ini terbangun dari sejumlah simbol-simbol, seperti juga halnya sebuah teks. 
Sebagai sebuah teks maka gejala sosial-budaya tersebut kemudian harus 'dibaca', ditafsir. Oleh karena gejala sosial-budaya tidak sama persis dengan 'teks' maka mau tidak mau diperlukan metode yang lain untuk membacanya, untuk menafsirnya. Di sinilah terletak perbedaan antara hermeneutik dalam kajian teks dengan hermeneutik dalam kajian gejala sosial-budaya.

Berbagai macam wujud pemaknaan al-Qur'an dengan berbagai simbol lain yang mengelilinginya merupakan teks-teks sosial-budaya yang dapat dibaca oleh mereka yang tertarik untuk meneliti The Living al-Qur'an. Dari kajian semacam ini akan muncul pemaknaan-pemaknaan atau tafsir-tafsir baru-yang berasal dari peneliti-mengenai 'pemaknaan-pemaknaan alQur'an' yang ada dalam berbagai kebudayaan, serta berbagai rituil yang menyertainya. Dalam hal ini, tafsir yang diberikan oleh peneliti tidak harus sama dengan tafsir masyarakat yang diteliti. Bahkan, memang harus berbeda, karena peneliti memiliki data kebudayaan yang lebih banyak daripada warga masyarakat itu sendiri secara individual. Hal ini memungkinkannya memberi tafsir yang berbeda atas berbagai macam fenomena Living al-Qur'an yang ditemuinya di tempat penelitian.

\section{F. Kesimpulan}

Dalam tulisan ini saya mencoba menunjukkan bahwa dalam kehidupan manusia sebagai animal symbolicum al-Qur'an bukan lagi hanya sebuah kitab yang dimaknai dengan cara yang sama, tetapi telah menjadi sebuah kitab dengan beraneka ragam pemaknaan, beraneka-ragam tafsir. Masing-masing tafsir yang diberikan sangat dipengaruhi oleh sistem budaya yang ada sebelum al-Qur'an itu sendiri muncul atau masuk ke dalam budaya tersebut. Dilihat dari perspektif ini, setiap bentuk pemaknaan pada dasarnya adalah sah dan dapat dibenarkan, sehingga tidak ada pemaknaan yang dapat dikatakan paling benar. 'Kebenaran' pemaknaan di sini memang bersifat relatif.

Mengingat al-Qur'an-secara empiris-merupakan sebuah perangkat simbol yang terdiri dari berbagai simbol berupa fonem-fonem bahasa Arab dalam tulisan Arab, yang tersusun menjadi satuan-satuan tertentu (fonem, morfem, kata, frasa, dst. hingga juz), maka al-Qur'an juga dapat didekati mengikuti satuan-satuannya, yang seringkali menimbulkan kesan sebagai pendekatan yang sepotong-sepotong. Bagi sebagian orang pendekatan semacam ini dianggap tidak tepat sama sekali, sedang bagi orang yang me- 
lakukannya pendekatan seperti ini dianggap sah-sah saja, sejauh itu dapat memenuhi kebutuhan tertentu, karena pendekatan semacam ini juga tidak dilarang.

Kenyataan bahwa al-Qur'an merupakan kitab berbahasa Arab-yang bagi mereka yang non-Arab (bahkan juga bagi sebagian orang Arab sendiri) makna-maknanya tidak selalu jelas dan mudah dimengerti-, semakin membuka kemungkinan munculnya pemaknaan yang sangat bervariasi. Variasi penafsiran inilah yang kemudian menda-sari munculnya berbagai fenomena sosial-budaya dengan nuansa qur'ani tertentu. Kehidupan manusia yang telah diwarnai atau dipengaruhi oleh apa yang ada dalam al-Qur'an dapat kita katakan sebagai fenomena "al-qur'anisasi kehidupan" atau "al-Qur-'an yang hidup," The Living al-Qur'an.

Qur'anisasi kehidupan atau kehidupan yang qur'ani merupakan wujud lain dari al-Qur'an sebagai sebuah kitab atau teks. Meskipun demikian, karena ciri-ciri dan sifat gejala ini berbeda dengan kitab atau teks dalam arti yang sebenarnya, maka upaya-upaya untuk mempelajari, menjelaskan atau memahaminya, memerlukan metode-metode yang berbeda pula. Di sinilah kajian al-Qur'an — sebagai sebuah teks yang 'hidup' dalam masyarakat—perlu memanfaatkan paradigma-paradigma yang telah berkembang dalam ilmuilmu sosial-budaya, seperti antropologi dan sosiologi.

Beberapa paradigma dalam antropologi yang dapat digunakan untuk meneliti, menelaah, atau menafsir "al-Qur'an yang hidup" antara lain adalah paradigma akulturasi, paradigma fungsional, paradigma struktural, paradigma fenomenologi dan paradigma hermeneutik. Penggunaan paradigma ini tentunya menuntut pemahaman yang memadai mengenai paradigmaparadigma ini sendiri. Masalahnya kemudian adalah, memadaikah pengetahuan kita saat ini mengenai paradigma-paradigma tersebut? Jawabnya ada pada diri kita sendiri.[w] 


\section{BIBLIOGRAFI}

Tim Disbintalad, Al-Qur'an Terjemah Indonesia, 2004.

Ahimsa-Putra, H.S., "Simbol, Tanda, Budaya dan Ilmu Budaya," makalah seminar, 2002. "Paradigma, Teori dan Metode," makalah seminar, 2004.

"The Living al-Qur'an: Beberapa Perspektif Antropologi," makalah workshop, 2007.

Badri, Y., Surat Tabaarak: Pendinding dari Siksa Kubur, alih bahasa oleh H.Nurullah dan F. Fauzan, Surabaya: Aneka Pustaka Islam., 1991.

Cassirer, E., An Essay on Man, New Haven: Yale University Press, 1945.

Ghazali, I., Menyembuhkan dengan Pengobatan Nabi, Jakarta: Pustaka Ibadah, 2003.

Hasan, H.S., Asmaul Husna: Keistimewaan, Khasiat dan Mengamalkannya, Surabaya: Amelia, 2003.

Labib M.Z., Rahasia di balik Kalamullah dan Khasiat Asma'ul Husna, Surabaya: Anugerah, t.th.

Lahmi, B., A. Rafi, KH.E. Syifa'i, Keistimewaan al-Asmaul Husna, Ayat Kursi, Basmalah, Jakarta: Pustaka Dwipar, 2002.

Mansur, M., "Living Qur'an dalam Lintasan Sejarah Studi Qur'an” dalam M. Mansyur, dkk., Metodologi Penelitian Living Qur'an dan Hadis, Yogyakarta: TH. Press, 2007.

Mustaqim, A., "Metode Penelitian Living Qur'an: Model Penelitian Kualitatif," dalam M. Mansyur, dkk., Metodologi Penelitian Living Qur'an dan Hadits, Yogyakarta: TH. Press, 2007.

Syamsudin, S., "Ranah-ranah Penelitian dalam Studi al-Qur'an dan Hadis" dalam M. Mansyur, dkk., Metodologi Penelitian Living Qur'an dan Hadits, Yogyakarta: TH. Press, 2007.

Umar, M.A.C., Khasiat dan Fadlilah Ayat Kursiy, Semarang: Toha Putra, 1979a. Khasiat dan Fadlilah al-Ikhlas, Semarang: Toha Putra, 1979b. 
Yusuf, M., "Pendekatan Sosiologi dalam Penelitian Living Qur'an" dalam M. Mansyur, dkk., Metodologi Penelitian Living Qur'an dan Hadis, Yogyakarta: TH. Press, 2007. 